\title{
APLIKASI KOLABORASI PROGRAM ARIAS DENGAN MASTER LEARNING DALAM MENGATASI PERMASALAHAN PEMAHAMAN RUBRIK PENILAIAN DI SD NEGERI 101789 MARENDAL - I
}

\author{
Asnarni Lubis ${ }^{1)}$, Nazriani Lubis ${ }^{2)}$ \\ Universitas Muslim Nusantara (UMN) Al Washliyah ${ }^{1)}$ \\ Universitas Muslim Nusantara (UMN) Al Washliyah²) \\ asnarnilubis@umn.ac.id
}

\begin{abstract}
ABSTRAK
Mitra di SD Negeri 101789 Desa Marendal - I Kabupaten Deli Serdang Provinsi Sumatera Utara, lokasi mitra yang berada di pinggir kota Medan, hal ini juga ditunjukkan dengan kelulusan peserta didik hanya dilihat dengan sederhana, bahkan kadang-kadang peserta didik tidak menerima tanda keberhasilan dalam pembelajaran, sesuai dengan target dan tujuan yang akan dicapai yaitu untuk pemahaman, metode pelaksanaan yang digunakan adalah kolaborasi ARIAS dengan MASTER Learning, alsannya karena kemudahan dalam mengikuti kegiatan. Hasil yang diperoleh mampu menghasilkan aktivitas kegiatan gambaran secara luas bahwa peserta, belum mampu dengan baik menghasilkan standar kelulusan yang sesuai dengan ketentuan atau kebutuhan peserta didik, kegiatan ini mampu meningkatan pemahaman peserta pengajaran abad 21, mengaplikasikan sintaks pembelajaran sesuai dengan kesiapan peserta, minat pengajaran dan indikator pemahaman rubrik penilaian abad 21. selanjutnya melalui analisis faktor adalah faktor minat pengajaran dan pengaajaran abad 21 sangat mempengaruhi kegiatan dalam proses dan pengaplikasian kolaborasi ARIAS dengan MASTER Learning. Dengan demikian dapat diketahui dengan kolaborasi ini mampu memberikan kontribusi peningkatan pemahaman mitra dalam menyelesaikan rubrik penilaian.
\end{abstract}

Kata Kunci : ARIAS dengan MASTER Learning, Keterbatasan, Rubrik Penilaian, Pemahaman

\begin{abstract}
Partners in SD Negeri 101789 Marendal Village - I Deli Serdang Regency, North Sumatra Province, the location of partners located in the suburbs of Medan, this is also shown by the graduation of students only be seen simply, even sometimes students do not receive signs of success in learning, in accordance with the targets and objectives to be achieved namely for understanding, the implementation method used is the collaboration of ARIAS with MASTER Learning, the reason being the ease of participating in activities. The results obtained are able to produce a broad picture of the activity activities that participants, have not been able to properly produce graduation standards in accordance with the provisions or needs of students, this activity is able to increase the understanding of 21 st century teaching participants, apply the syntax of learning in accordance with the readiness of the participants, teaching interests and indicators of understanding the 21 st Century rubric assessment. Next through factor analysis is the 21 st century teaching and teaching interest factors which greatly influence the activities in the process and the application of ARIAS collaboration with MASTER Learning. Thus it can be seen that this collaboration can contribute to increasing partner understanding in completing the assessment rubric.
\end{abstract}

Keywords: ARIAS with MASTER Learning, Limitations, Assessment Rubric, Understanding 


\section{PENDAHULUAN}

\subsection{Latar Belakang}

Mitra pada pengabdian ini adalah SD Negri 101789 Marendal I yang berada di Desa Marendal - I, Kecamatan Patumbak, Kabupaten Deli Serdang. SD Negri 101789 Marendal - I merupakan sekolah yang memiliki 24 guru, 539 siswa, 18 kelas dan masih berakreditasi C. Lokasi mitra dari Universitas Muslim Nusantara (UMN) Al Washliyah sebesar 3,6 $\mathrm{Km}$ atau 14 menit menggunakan kendaraan mobil. Lokasi yang berada dipinggiran kota dan berda di wilaayah PTPN II menjadikan lokasi mitra sangat tepat dijadikan dasar mitra. Hal yang menjadi kelayakan mitra adalah mitra belum pernah mendapatkan bimbingan secara khusus dalam kegiata evaluasi pembelajaran.

Melalui observasi di skeolah diketahui belum terlaksana dengan baik standar penilaian kelulusan bagi peserta didik yang mengikuti kegiatan pembelajara, artinya kegiatan pembelajaran hanya dilakukan masih dalam keadaan seadanya, sehinga pemiliki mengatakan sangat dibutuhkan ada masukan dari pihak-pihak lain dalam menjalankan dan menitikberatkan keberhasilan peserta didik dalam mengikuti kegiatan. Dalam proses penilaian guru masih sangat rendah atau belum sesuai dengan salah satu harapan, selanjutnya diketahui berdasarkan wawancara dengan salah satu guru, bahwa mereka memberikan pembelajaran tanpa mengetatahui standar kelulusan yang akan dicapai, jika peserta didik sudah paham, maka guru akan menganggap sudah lulus dalam menyelesaikan materi, sehingga peserta didik datang mendapat pengetahuan baru, dengan reward berupa pujian, tetapi tidak ada penilaian kelulusan seacara khusus. Dengan demikian, jelas diketahui diperlukan standar penilaian kelulusan pada lembaga ini yang disesuaikan dengan yang diharapkan pada K-13. Penilaian yang mengalami permasalahan dan kesulitan yang dipahami oleh guru berkaitan dengan penilaian yang tepat diberikan kepada peserta didik.

Dengan demikian, hal ini menjadi perhatian untuk mewujudkan lebih baik lagi standar kelulusan yang disesuaikan dengan kebutuhan peserta didik, terutama mencapai tujuan kompetensi pada K13 bukan hanya mahir menyelesaikan masalah dalam pembelajaran atau tugas peserta didik namun juga menilai keberhasilan dalam pembelajaran. Untuk memudahkan dan mengasah kemahiran dalam memahami dengan tepat bagaimanakah guru yakin bahwa peserta didik berhasil mengikuti setiap program. Dalam hal diperlukan kemahiran guru dalam membuat standar penilaian kelulusan peserta didik.

Barlet (dalam Abidin, 2016:6) menegaskan bahwa penilaian pembelajaran dipandang menjadi sepuluh terminologi yaitu perencanaan pembelajaran yang efektif, bagaimana peserta didik belajar, praktek di kelas, keterampilan profesional, sensitive, konstruktif, motivasi peserta didik pemahaman terhadap tujuan, kriteria yang telah ditetapkan serta mengembangkan penilaian diri dan prestasi pendidikan .

Dalam hal ini menegaskan bahwa guru harus memiliki standar penilaian kelulusan yang akan disesuaikan dengan proses pembelajaran atau tujuan lembaga menghasilkan peserta didik yang 
cerdas dan kreatif, hal ini sesuai dengan komptensi inti yang diharapkan pada Kurikulum 2013 (K13) yaitu pada KI-2 sikap, KI-3 keterampilan dan KI-4 pengetahuan, sehingga peserta didik memperoleh kemudahan dalam proses mengikuti setiap kegiatan dan memiliki kemampuan yang sama dalam proses pencapaiannya.

Pembuatan standar penilaian kelulusan pada mitra akan mempermudah setiap kegaitan yang akan dilakukan guru kepada peserta didik, dengan menciptakan suasana pendidikan yang kreatif, inovatif, dinamis, diaglogis. Hal ini ditegaskan pada Pasal 40 Ayat 2 UU No.20 Tahun 2003 dengan penjelasan setiap pendidik berkewajiban untuk menciptakan suasana pendidikan yang bermakna, menyenangkan, kreatif, dinamis, dan dialogis, mempunyai komitmen secara profesional untuk meningkatkan mutu pendidikan, memberi teladan dan menjaga nama baik lembaga, profesi, dan kedudukan sesuai kepercayaan yang diberikan kepadanya (Anderson dan Krathwohl, 2017:6).

\subsection{Tujuan Pengabdian}

Tujuan pengabdian ini adalah:

a. Untuk mengetahui kesiapan mitra dalam menyelesaikan rubrik penilaian

b. Untuk mengetahui aktivitas kegiatan mitra dalam mengikuti kegiatan, sehingga mengetahui solusi yang akan diberikan.

c. Untuk menganalisis peningkatan pemahaman mitra dalam memahami standar kelulusan dan rubrik penilaian peserta didik.

\subsection{Metode Pendekatan Pemecahan Masalah}

Dari permasalahan yang dijelaskan diatas, dengan memfokuskan pada pembuatan dan kemahiran guru dalam menyelesaikan rubrik penilaian berdasarkan Kurikulum 2013, maka akan ditawarkan solusi sebagai berikut: Kegiatan ini juga dilaksanakan berdasarkan penelitian Lubis, A (2018) menjelaskan bahwa dengan aplikasi MASTER learning mampu memberikan kesempatan aktif dalam setiap kegiatan dengan mengintegrasikan dengan ARIAS mampu memberikan keberhasilan dan kepercayaan diri peserta dalam mengikuti setiap kegiatan

Hal ini menekankan pada keunggulan MASTER learning diantaranya adalah dapat meningkatkan pemahaman peserta terhadap materi yang disajikan, memberikan kesempatan peserta terlibat aktif dalam diskusi dan mengajak mahasiwa mencari makna atau mengkaitkan materi yang telah dipelajari dengan situasi dunia nyata dan menjadikan pembelajaran lebih menyenangkan dan mengembangkan kemampuan berpikir kreatif peserta (Safitri, et.al, 2014:1).

\section{METODE PELAKSANAAN}

Program ARIAS ini akan memudahkan mengaktifkan komunikasi interpersonal, dengan mengaktifkan komunikasi interpersonal akan memberikan kesempatan anak untuk melakukan interaksi sosial, percaya diri, hasil belajar hingga penghargaan, sehingga dengan ARIAS akan mampu memberikan stimulus yang tepat dan efektif (Juhayl, et.al, 2013:122).

Dalam hal ini ARIAS akan dikaitkan dengan MASTER learning, yaitu pada tahapan Assurance 
(Percaya Diri) dikaitkan dengan Motivating Your Mind yaitu peserta mendengarkan narasumber memberikan pengarahan, sehingga timbul rasa percaya diri dan penguatan dalam mengikuti kegiatan, Relevance (Menghubungkan dengan Kehidupan Sehari-Hari) dikaitkan dengan Aquiring The Information peserta mengambil, memperoleh dan menyerap fakta-fakta sesuai dengan gagasan inti dan menyesuaikan dengan apa yang dilihat dan didengar. Interest (Minat/Perhatian) Searching dikaitkan denga Out the Meaning peserta menyelidiki makna seutuhnya secara seksama dengan mengeksplorasi bahan sesuai dengan materi yang disajikan, Assesment (Penilaian) dikaitkan dengan Triggering the Memory peserta diperintahkan untuk mengulang semua jawaban yang diperoleh sesuai permasalahan yang diberikan dan dikaitkan dengan Exhibiting What You Know peserta diberikan kesempatan untuk membuktikan, mempraktikan atau mempresentasikan atas jawaban yang tepat baik dengan teman dan tahapan terakhir diberikan dengan melaksanakan Satisfaction (penguatan) dikaitkan dengan Reflecting How You've Learned peserta diberikan kesempatan untuk menemukan cara yang tepat, sehingga terjadi penguatan dan kepuasan dalam kegiatan yang dilakukan.

Sehingga dapat digambarkan sebagai berikut:

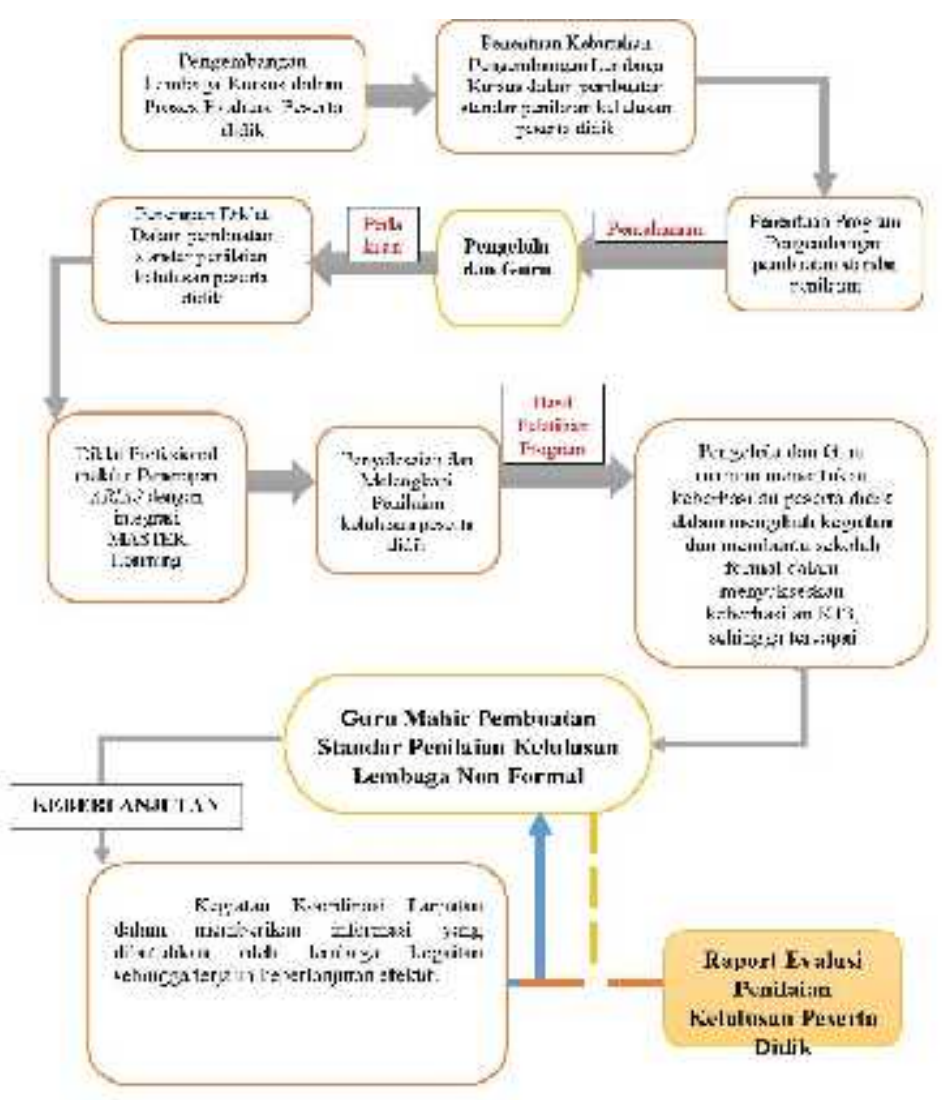

Gambar 1. Gambaran Metode Pelaksanaan, Evaluasi dan Keberlanjutan Program 
Kegiatan ini akan terlaksana, dengan langkah-langkah berikut:

Tabel 1. Kegiatan Program ARIAS dengan MASTER Learning

\begin{tabular}{|c|c|c|}
\hline Model ARIAS & Sintaks Dalam MASTER & Kegiatan Mahasiswa \\
\hline $\begin{array}{l}\text { Assurance (Percaya } \\
\text { Diri) }\end{array}$ & Motivating Your Mind & $\begin{array}{l}\text { Peserta mendengarkan pengabdi memberikan } \\
\text { pengarahan, sehingga timbul rasa percaya diri dan } \\
\text { penguatan dalam mengikuti pembelajaran }\end{array}$ \\
\hline $\begin{array}{l}\text { Relevance } \\
\text { (Menghubungkan } \\
\text { dengan Kehidupan } \\
\text { Sehari-Hari) }\end{array}$ & Aquiring The Information & $\begin{array}{l}\text { Peserta mengambil, memperoleh dan menyerap } \\
\text { fakta-fakta sesuai dengan gagasan inti dan } \\
\text { menyesuaikan dengan apa yang dilihat dan } \\
\text { didengar. }\end{array}$ \\
\hline $\begin{array}{l}\text { Interest } \\
\text { (Minat/Perhatian) }\end{array}$ & Searching Out the Meaning & $\begin{array}{l}\text { Peserta menyelidiki makna seutuhnya secara } \\
\text { seksama dengan mengeksplorasi bahan sesuai } \\
\text { dengan materi yang disajikan }\end{array}$ \\
\hline \multirow[t]{2}{*}{ Assesment (Penilaian) } & Triggering the Memory & $\begin{array}{l}\text { Peserta diperintahkan untuk mengulang semua } \\
\text { jawaban yang diperoleh sesuai permasalahan } \\
\text { yang diberikan }\end{array}$ \\
\hline & Exhibiting What You Know & $\begin{array}{l}\text { Peserta diberikan kesempatan untuk } \\
\text { membuktikan, mempraktikan atau } \\
\text { mempresentasikan atas jawaban yang tepat baik } \\
\text { dengan teman atau tim pengabdi. }\end{array}$ \\
\hline $\begin{array}{l}\text { Satisfaction } \\
\text { (penguatan) }\end{array}$ & $\begin{array}{l}\text { Reflecting } \\
\text { Learned }\end{array}$ & $\begin{array}{l}\text { Peserta diberikan kesempatan untuk menemukan } \\
\text { cara belajar yang tepat, sehingga terjadi } \\
\text { penguatan dan kepuasan dalam pembelajaran }\end{array}$ \\
\hline
\end{tabular}

(Sumber: Lubis, 2018:181)

\section{HASIL DAN PEMBAHASAN}

Pengabdian dilaksanakan di SD Negeri 101789 Marendal - I, sekolah tersebut sangat menyambut dan memberikan respon yang sangat menyenangkan, bahkan setiap guru memiliki rasa ingin tahu yang sangat baik dalam proses pengabdian. Pengabdian yang berlangsung memberikan peningkatan pemahaman yang baik, keterlibatan dalam proses pelaksanaan sangat menjadi patokan penilaian keberhasilan pengabdian.

Dari gambar 2, menjelaskan kegiatan pengabdian memberikan hasil penilaian aktivitas kegiatan, keberhasilan tersebut, dijelaskan pada gambar grafik berikut:

\section{Grafik Observasi Kegiatan Pengabdian}

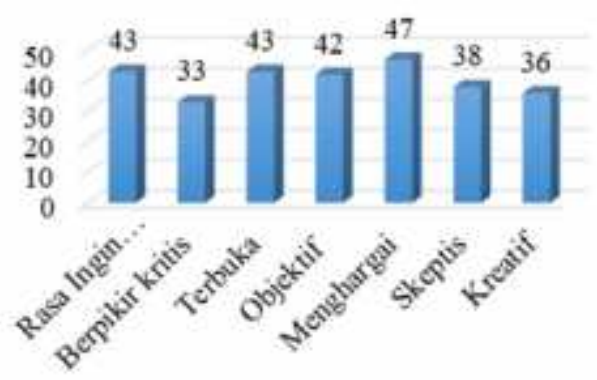

Gambar 2. Grafik Batang Observasi Kegiatan Pengabdian

Dari grafik di atas, diketahui dengan jelas, bahwa aktivitas kegiatan pengabdian berlangsung saling menghargai, hal ini terlihat bahwa peserta pengabdian memperoleh nilai sebesar 47, saling menghargai menjadi kunci keberhasilan pengabdian, selanjutnya rasa ingin tahu dan keterbukaan para peserta juga menjadikan proses 
kegiatan pengabdian menjadi berlangsung dua arah, sehingga memberikan tanya jawab dan komunikasi menjadi lebih menarik, diperoleh dengan nilai sebesar 43 . Selanjutnya aktivitas lainnya terlihat jelas bahwa sikap objektif yang ditunjukkan peserta, kurang pahamnya peserta tentang standar penilaian yang harus dilakukan dalam proses pembelajaran, dalam hal ini beberapa peserta mengakui bahwa mampu menilai dengan baik walau terkadang tidak mampu menjelaskan dengan rinci dari mana hasil yang telah diperoleh, hal ini diperoleh nilai sebesar 42 . Selanjutnya kegiatan ini menjadi lebih terlihat kemampuan peserta dalam menuliskan standar penilaian kepada peserta didik, setelah dilakukan kegiatan diketahui bahwa aktivitas ini juga memperlihatkan sikap skeptis peserta dalam melaksanakan pengabdian sebesar 38.

Tim pengabdi memasang video kegiatan pembelajaran dengan menunjukkan cara pembuatan baterai, ketika ditanyakan kepada peserta, peserta belum mampu kreatif untuk menemukan jawaban, ketika pertanyaan "apa yang harus dilakukan atau strategi pembelajaran apa yang tepat dilakukan", guru hanya menjawab satu strategi dan selanjutnya tim pengabdi memberikan pertanyaan kembali 'penilaian apa yang akan diberikan kepada peserta didik dalam pembelajaran?"., Jawaban peserta belum sesuai harapan, artinya guru belum kreatif menilai standar kelulusan dan mahir dalam menentukan rubrik penilaian yang harus dilakukan, hal ini ditunjukkan sebesar 36, sama halnya pertanyaan tersebut juga menegasakan bahwa peserta belum mampu membangkitkan cara berpikir kritis dalam melaksanakan pembelajaran ditunjukkan dengan nilai sebesar 33 .

Dapat disimpulkan bahwa setiap aktivitas kegiatan yang telah dilaksanakan dalam lembar obeservasi memberikan gambaran secara luas bahwa peserta SD Negeri 101789 Marendal - I, belum mampu dengan baik menghasilkan standar kelulusan yang sesuai dengan ketentuan atau kebutuhan peserta didik, bahkan dalam aktivitas kegiatan ini diketahui bahwa peserta belum mahir dalam menuliskan rubrik penilaian, untuk menyampaikan secara objektif kepada peserta didik tentang keberhasilan yang diperoleh. Namun dalam kegiatan ini, memperlihatkan rasa ingin tahu, menghargai dan sikap terbuka dalam menerima pengetahuan dan pemahaman yang seharusnya yang dilakukan, bahkan salah satu peserta menyatakan merasa kesulitan dalam melaporkan penilaian untuk Kurikulum 2013 saat ini.

Melalui penerapan pengabdian masyarakat memberikan kesiapan pemahaman lebih baik, peserta memahami dengan baik untuk meningkatkan pemahaman peserta dalam menyelesaikan hal yang tepat dalam proses evaluasi atau penilaian, berikut hasil peningkatan yang diperoleh pada saat pengabdian:

1. Peningkatan pemahaman yang paling tinggi dihasilkan tentang pemahaman peserta pengajaran abad 21, hal ini menegaskan bahwa setiap guru bahwa pembelajaran abad 21 sesuai dengan perkembangan industri 4.0 artinya peserta menyadari dan menyetujui bahwa pembelajaran abad 21 harus mampu 
membangkitkan dan menilai peserta didik dengan baik dan benar bahkan objektif. Peningkatan pemahaman pentingnya mengaplikasikan pembelajaran abad 21 serta menyiapkan penilaian yang sesuai adalah hal penting ditingkatkan. Peningkatan pemahaman ini diperoleh sebesar $15,62 \%$.

2. Peningkatan pemahaman selanjutnya juga ditunjukkan para peserta untuk mengaplikasikan sintaks pembelajaran sesuai dengan kesiapan peserta dalam melaksanakan pembelajaran melalui langkah-langkah yang tepat, sehingga dengan sintaks akan memudahkan setiap aspek penilaian Kurikulum 2013, peningkatan ini memperoleh nilai sebesar $14,58 \%$.

3. Peningkatan selanjutnya ditunjukkan pada indikator minat pengajaran, dengan minat yang baik memberikan rasa ingin tahu dalam menyelesaikan pembelajaran yang baik, minat pengajaran sangat erat hubungan dengan aktivitas yang dihasilkan peserta dalam kegiatan pengabdian. Antusias yang ditunjukkan tentang tanya jawab bagaimana pembelajaran menarik, hal ini ditunjukkan nilai sebesar $14,45 \%$

4. Peningkatan terakhir adalah pada indikator pemahaman rubrik penilaian abad 21. Dalam hal ini diketahui bahwa peserta mulai memahami rubrik penilaian abad 21 dan pentingnya menilai dengan baik dalam menuliskan rubrik penilaian (sikap, pengetahuan dan keterampilan). Dalam pelaksanaan pengabdian ini memberikan kontribusi kepada peserta untuk menyelesaikan rubrik penilaian. Diketahui hasil yang diperoleh sebesar $14,06 \%$.

Dengan demikian, diketahui dengan jelas bahwa pelaksanan pengabdian ini memberikan informasi dan meningkatan pemahaman, bahwa peserta lebih menyiapkan pembelajaran abad 21 dengan baik, didahulukan dengan memahami

strategi/pendekatan/model yang digunakan dalam pembelajaran, sintaks yang sesuai dan diseleraskan dengan penilaian yang akan diselesaikan, penilaian bersifat objektif dengan menyelesaikan rubrik penilaian yang tepat dan benar.

\section{KESIMPULAN}

Berdasarkan kegiatan yang dilakukan dengan menggunakan metode kolaborasi ARIAS dengan MASTER learning, maka dapat disimpulkan:

a. Kegiatan ini mampu aktivitas kegiatan yang telah dilaksanakan dalam lembar obeservasi memberikan gambaran secara luas bahwa peserta SD Negeri 101789 Marendal - I, belum mampu dengan baik menghasilkan standar kelulusan yang sesuai dengan ketentuan atau kebutuhan peserta didik, bahkan dalam aktivitas kegiatan ini diketahui bahwa peserta belum mahir dalam menuliskan rubrik penilaian, untuk menyampaikan secara objektif kepada peserta didik tentang keberhasilan yang diperoleh. Namun dalam kegiatan ini, memperlihatkan rasa ingin tahu, menghargai dan sikap terbuka dalam menerima pengetahuan 
dan pemahaman yang seharusnya yang dilakukan, bahkan salah satu peserta menyatakan merasa kesulitan dalam melaporkan penilaian untuk Kurikulum 2013 saat ini.

b. Kegiatan ini mampu meningkatan pemahaman peserta pengajaran abad 21 sebesar $15,62 \%$, mengaplikasikan sintaks pembelajaran sesuai dengan kesiapan peserta sebesar $14,58 \%$, minat pengajaran ditunjukkan nilai sebesar 14,45 dan indikator pemahaman rubrik penilaian abad 21 diketahui hasil yang diperoleh sebesar $14,06 \%$.

\section{UCAPAN TERIMA KASIH}

Ucapan Terima kasih kepada Pihak Univeristas Muslim Nusantara (UMN) Al Washliyah memberikan kepercayaan, kesempatan dan dana dalam menyelesaikan program ini.

\section{REFERENSI}

Abidin., 2016. Revitalisasi Penilain Pembelajaran dalam Konteks Pendidikan Multiliterasi Abad $\mathrm{Ke}$ - 21. Cetakan Kesatu. Bandung. PT.Refika Aditama. Hal:6

Anderson dan Krathwohl., 2017. Kerangka Landasan Untuk Pembelajaran, Pengajaran dan Asesmen. Revisi Taksonomi Pendidikan Bloom. Penerjamah Agung Prihantoro. Cetakan II. Yogyakarta. Penerbit Pustaka Belajar. Hal:6
Antonius., 2016. Buku Pedoman Guru. Cetakan II. Bandung. Penerbit Yrama Widya. Hal:135

Juhayla., Hobri \& Sugiarti. 2013. Penerapan Model Pembelajaran ARIAS (Assurance, Relevance, Interest, Assessment, Satifaction) Untuk Mengurangi Kesalahan Menyelesaikan Soal Keliling dan Luas Bangun Datar Siswa Kelas X SMK Negeri 1 Jember Tahun Ajaran 2012/2013. Jurnal Kadikma. 4 (3). Halaman:122

Lubis., 2018. Model Pembelajaran Arias Dengan Master Learning Dalam Meningkatkan Hasil Belajar Dan Kepercayaan Diri Belajar Kimia Umum. Jurnal Penelitian Pendidikan MIPA. Volume 3 Nomor 1. Hal:18

Safitri., Kristiantari., Suryaabadi. 2014. Pengaruh Model Pembelajaran MASTER Berbantuan Media Ceritaa Rakyat Terhadap Keterampilan Membaca Siswa Pada Pelajaran Bahasa Indonesia Kelas V SDN 12 Padangsambian. Jurusan Pendidikan Guru Sekolah Dasar. Universitas Pendidikan Ganesha, Singaraja. E-Journal Mimbar PGSD Universitas Pendidikan Ganesha, 2 (1). Hal:1 